\title{
The impact of ambiguous stimuli on work memory capacity and reaction time in patients with post-traumatic stress disorder
}

\author{
Vida Mirabolfathi', Alireza Moradi²,3* iD, Mohammad Hasan Choobin ${ }^{4}$, Nazanin Derakhshan ${ }^{5}$ \\ 1. PhD Student in Cognitive Psychology, Cognitive Psychology Department, Institute for Cognitive Science Studies, Tehran, Iran \\ 2. Professor of Clinical Psychology, Department of Clinical Psychology, Kharazmi University, Tehran, Iran \\ 3. Professor of Clinical Psychology, Department of Cognitive Psychology, Institute for Cognitive Science Studies, Tehran, Iran \\ 4. MSc in Clinical Psychology, Kharazmi University, Tehran, Iran \\ 5. Professor of Experimental Psychology, Department of Psychology, Birkbeck University of London, London, United Kingdom
}

Recieved: 9 Jul. 2019

Revised: 28 Aug. 2019

Accepted: 3 Sep 2019

\section{Keywords}

Post-traumatic stress disorder Working memory capacity

Speed processing

Corresponding author

Alireza Moradi, Professor of

Clinical Psychology, Department

of Clinical Psychology, Kharazmi

University, Tehran, Iran

Email: Moradi@khu.ac.ir

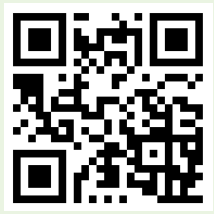

\section{Abstract}

Introduction: People with post-traumatic stress disorder suffer from different cognitive and emotional problems. Meta-analyses studies investigating PTSD cognitive functions have been revealed that working memory and speed processing are two vital components that can explain PTSD's cognitive dysfunctions. This study aims to investigate emotional working memory capacity and speed of processing via an emotional working memory capacity task.

Methods: A total number of 50 participants (20 PTSD, 15 Non-PTSD, 15 healthy control) from road traffic accident recruited via social media advertisements. All participants screened based on SCID and then invited for the working memory and speed processing assessment session. In this study, The Impact of Event Scale-Revised, Hopkins Symptom Checklist, and emotional working memory capacity task has been used.

Results: Mixed ANOVA repeated measure has revealed that speed processing in the PTSD group is significantly lower than the Non-PTSD group. Also person correlation has revealed that in the PTSD group reaction time in the adequate correct response trials with trauma-related distractors has a negative correlation with avoidance and hyperarousal symptoms and also there is a significant negative correlation between reaction time in the correct responses in trials with white noise distractor and intrusion-related symptoms in PTSD group.

Conclusion: It seems that exposure with vague distractors (white noise) can result from more intrusion and less cognitive efficacy, requiring more investigation in future studies.

Citation: Mirabolfathi V, Moradi A, Choobin M H, Derakhshan N. The impact of ambiguous stimuli on work memory capacity and reaction time in patients with post-traumatic stress disorder. Advances in Cognitive Sciences. 2020;22(1):49-60. 
(D)

\title{
تاثير مواجه با محر ك مبهم در ظرفيت حافظه كارى و سرعت واكنش در مبتلايان به اختلال استرس پس از سانحه
}

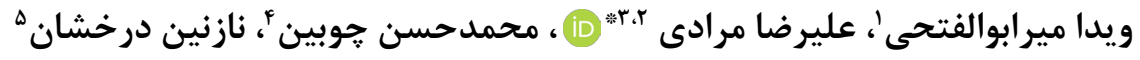 \\ ا. دانشجوى دكترى روانشناسى شناختى، كروه روان شناسى شناختى، موسسه آموزش عادئ عالى علوم شناختى، تهران، ايران

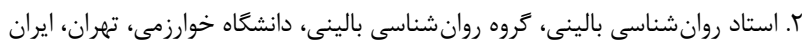

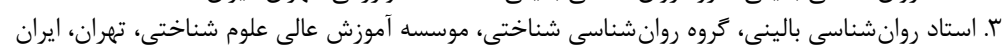

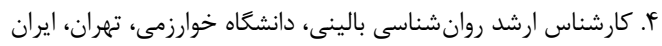

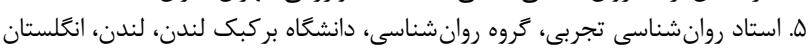

\begin{abstract}
are
مقدمهه: اختلال استرس يس از سانحه با مشكلات شناختى و هيجانى متعددى همراه است.نتايج مطالعات فراتحليلى حاكى است كه حافظه كارى و سرعت يردازش دو مولفه مجزا با اندازه اثر بالا در بررسى نواقص شناختى اين اختلال مى باشند. هدف يزوهش حاضر بررسى سرعت يردازش و ظرفيت حافظه كارى هيجانى در افراد مبتلا به اختلال استرس پِ از سانحه بود كه هر دو با استفاده از تكليف ظرفيت حافظه كارى مورد بررسى قرار گرفته تا تصوير كاملترى از مشكلات شناختى اين اختلال بدست دهد. روش كار: در اين مطالعه · r فرد مبتلا به اختلال استرس پس از سانحه ناشى از تصادف، ها شركت كننده دركير در تصادفات جاده اى بدون علائم اين اختلال و ها نفر فردى كه در طول عمر خود با تصادف شديد رانندكى مواجه نشده بودند به صورت در دسترس انتخاب و پِس از انجام مصاحبه تشخيصى مورد ارزيابى حافظه و سرعت يردازش قرار گرفتند. در اين مطالعه از مصاحبه ساختار يافته بر اساس DSM-5، مقياس تجديد نظر شده تاثير رويداد، يرسشنامه علائم روانيزشكى Hopkins براى ارزيابى نشانههاى افسردگى و تكليف ظرفيت حافظه كارى ديدارى براى ارزيابى ظرفيت حافظه كارى و سرعت يردازش استفاده شد. يافته ها: آزمون تحليل واريانس مختلط با اندازميرىهاى مكرر نشان داد كه سرعت واكنش افراد مبتلا به اختلال استرس يس از سانحه در تمام موقعيتهاى تكليف ظرفيت حافظه كارى به صورت معنادار آهستهتر از تروه Non-PTSD بود. علاوه بر اين همبستكى منفى معنادار ميان علائم مرتبط با بيش تحريكيذيرى، اجتناب و سرعت واكنش پاسخهاى صحيح در كوششهاى داراى تصاوير تصادف مشاهده شد. همجنين همبستگى مثبت معنادار ميان علائم مرتبط با افكار مزاحمو سرعت واكنش ياسخهاى صحيح در كوششهاى دارى تصاوير مبهزم (مغشوش) بدست آمد. نتيجه كَيرى: بر اساس نتايج بدست آمده به نظر مى رسد كه مواجه با تصاوير مبهم (مغشوش) با افزايش افكار مزاحم منجر به كاهش كار آمدى شناختى در مبتلايان به اختلال استرس يس از سانحه مى گردد كه نياز به بررسى بيشتر در مطالعات آينده دارد.
\end{abstract}

دريافت:

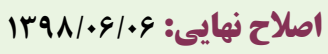
يذيرش: وازههاى كليلدى اختلال استرس يس از سانحه حافظه كارى احنل استرس سرعت پيردازش

نويسنله مسئول

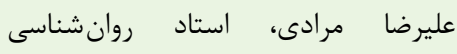
بالينى، گروه روانشناسى بالينى، دانشعاه خوارزمى، تهران، ايران

ايميل:Moradi@khu.ac.ir

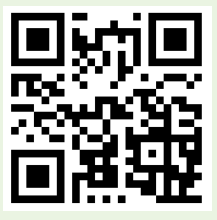

dol doi.org/10.30699/icss.22.1.49

مقلدمه

(1). به جز اختلال در خلق و هيجان، مشكلات شناختى، از شكايتهاى عمده مبتلايان به PTSD است كه عمدتا شامل اختلال در حافظه، فرايندهاى توجه و كنترل شناختى مى گردد (r). Scott و همكارانش در يك مطالعه فراتحليلى كه شامل بررسى •9 مقاله در اين حوزه بود، بيان كردند كه يادكيرى كلامى، سرعت يردازش، توجه و حافظه كارى traumatic stress disorder (PTSD)) اختلال استرس يس از سانحه يك بيمارى روانيزشكى شديد است كه مىتواند بعد از تجربه يا مشاهده حادثه آسيبزا (Traumatic) رخ داده و علائمى همجٍون تجربه مجدد حادثه آسيبزا، اجتناب از محركهاى مرتبط با حادثه آسيبزا، افزايش تحريك يذيرى، عاطفه منفى و افكار مزاحم مكرر را به دنبال دارد 
اطلاعات ديدارى_فضايى و كلامى به طور همزمان بود، مجددا نشان دادند كه ظرفيت حافظه كارى هيجانى در مبتلايان به PTSD، كمتر از كروه

مواجه شده با تصادف اما بدون اختلال Non-PTSD مى باشد (V).

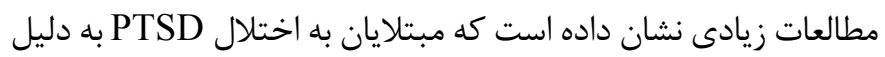

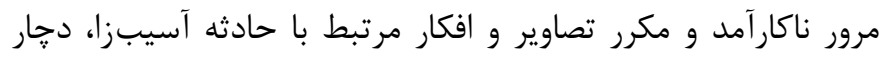
واكنش اغراق شده هيجانى در مواجه با محرك هاى منفى و بالاخص

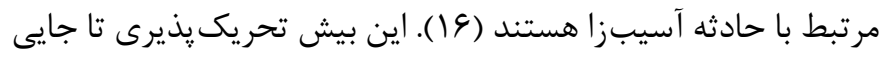
است كه مىتواند به تفسير منفى و با مفهوم تهديدكننده از محر كهاى مبهم و يا خنثى نيز منجر شود (IV). مطالعات اخير نشان مى دهد كه

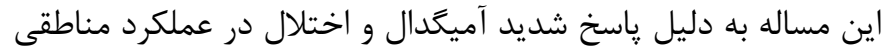
از مغز نظير قشر קِيشيشانى ميانى جانبى، پيشانى خلفى و قشر

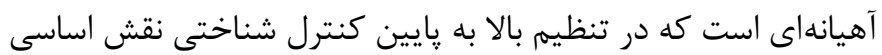

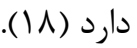
آسيب حافظه كارى جه در بافت تكاليف هيجانى جه در ساختار ارزيابى

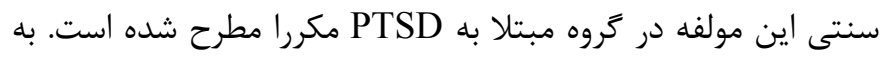

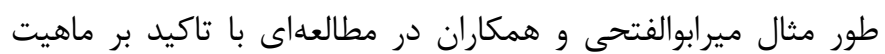
ديدارى علائم اين اختلال با استفاده از تكليف بازشناسى ديدارى جهره

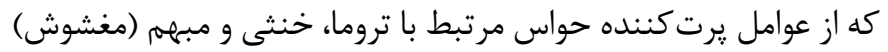
تشكيل شده بود، نقص عملكرد حافظه كارى هيجانى در مبتلايان به

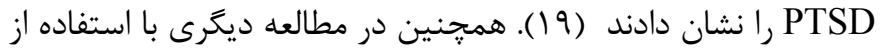
نسخه بازبينى شده همان تكليف نقش واسطهاى علائم مرتبط با اجتناب

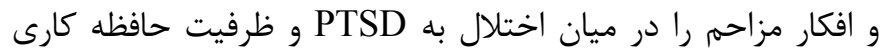

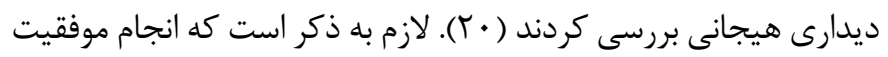

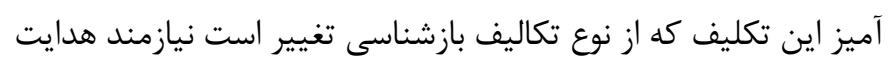

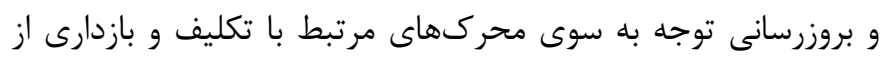
اطلاعات نامرتبط با تكليف مىباشد (Iآ). در اين مطالعه نشان داده شد كه در كوششهاى داراى زمينه هيجانى، علائم مرتبط با اجتناب و افكار مزاحم نقش ميانجى در تشخيص PTSD و ظرفيت حافظه كارى را دارند. اين يافته بيان مى كند كه ظرفيت حافظه كارى كمتر، در مواجه با تصاوير تصادف با علائم مرتبط با اجتناب و افكار مزاحم بيشتر در

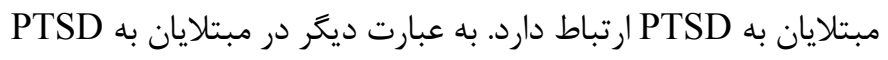

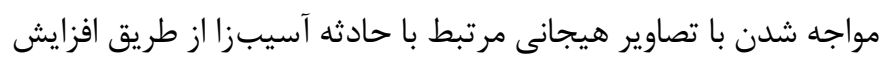

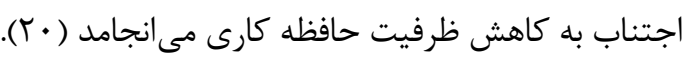

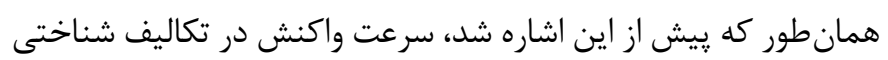

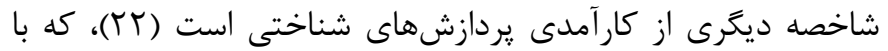

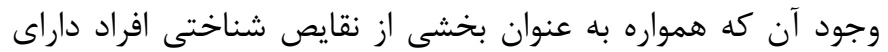
PTSD در نظر ترفته شده است اما همواره در بافت تكاليف ارزيابى
بيشترين اندازه اثر را در مجموعه آسيبهاى شناختى گروه مبتلا به PTSD نشان مى دهد (r) Pآ.

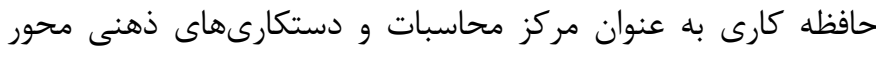

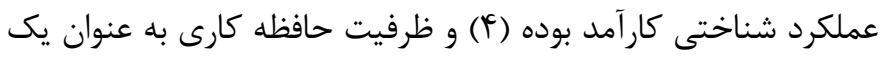

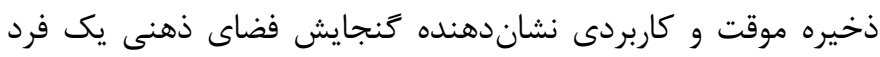

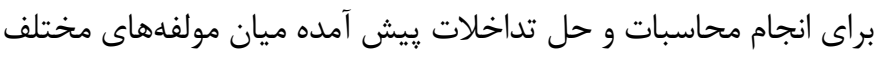

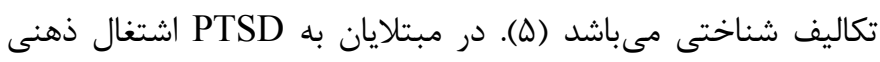
مداوم با تصاوير و افكار مزاحم مرتبط با حادثه آسيبزا و نشخوار افكار منفى با اشغال اين ظرفيت محدود منجر به شكست در انجام فعاليتهاى شناختى روزمره مىشود (Y) (V). سرعت يردازش به عنوان يك مولفه شناختى مههم در كنار ظرفيت حافظه

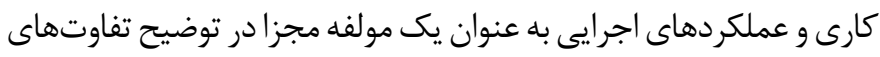

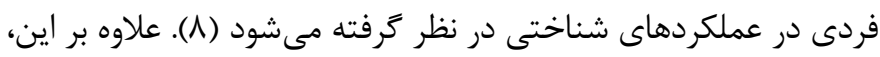

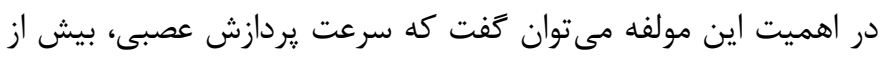

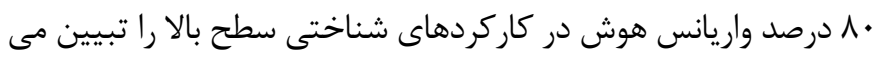

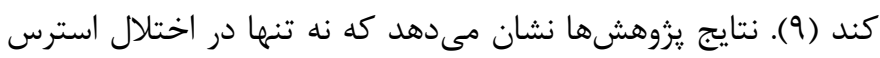

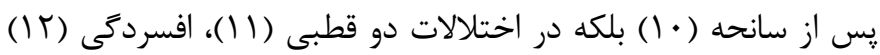

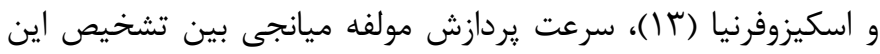
اختلالها و نقايص حافظه در آنها مىباشد. نكته مهم در مبتلايان به PTSD آن است كه مطالعات عصبشناختى نشان داده است كه مبتلايان

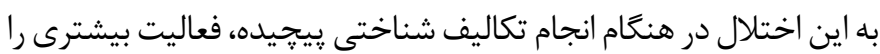

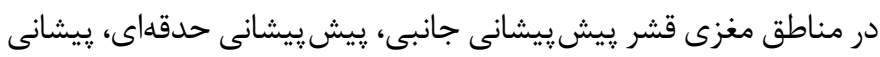

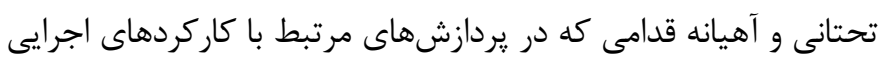

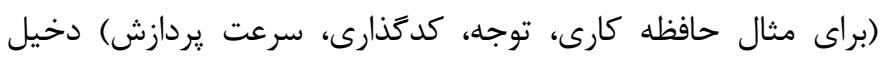

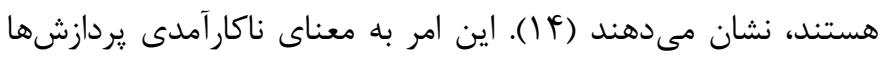
در سطح عصبى بوده و شاهدى بر آسيب كاركردهاى شناختى در سطح رفتارى مىباشد. از اين رو در اين گروه فعاليت بيشتر مناطق مغزى مرتبط نه تنها منجر به بهبود عملكرد نشده، بلكه با كاهش معنادار فعاليت شناختى نيز همراه است. در همين راستا و براى مطالعه ظرفيت حافظه كارى در بافتارى نزديك به موقعيتهاى روزمره زندكى، Schweizer و (Y. Dalgleish

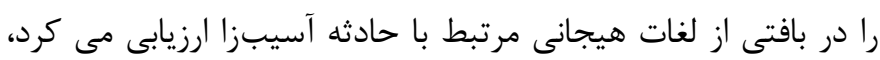

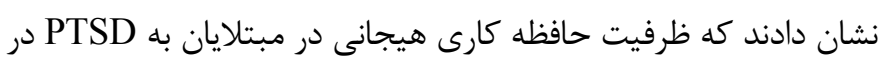
مقايسه با افراد مواجه شده با حادثه آسيبزا بدون علائم مرتبط با اين دان

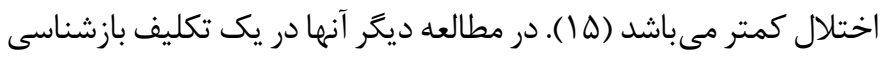
״يجֶيده براى ارزيابى ظرفيت حافظه كارى كلامى و ديدارى با استفاده از عوامل يرتكننده حواس هيجانى كه نيازمند كدگذارى و فراخوانى 
براى ارزيابى نشانهاى افسردىى و تكليف ظرفيت حافظه

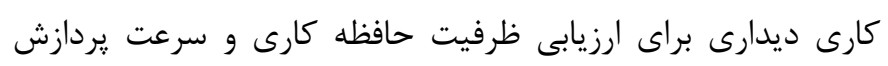

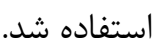

مصاحبه بالينى ساختاريافته بر اساس (SSM-5 (SCID DSM-5)) (Structured Clinical Interview for

مصاحبه مذكور يك ابزار جامع و استاندارد براى ارزيابى اختلالات روانيزشكى بر اساس ملاكهاى تشخيصى DSM-5 طراحى شده

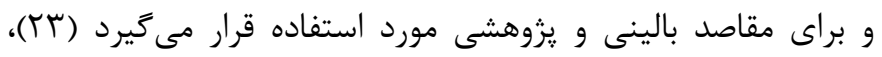

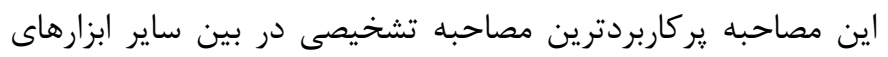

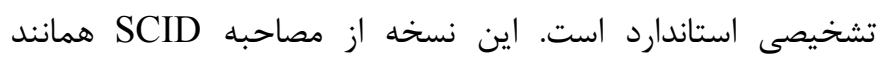

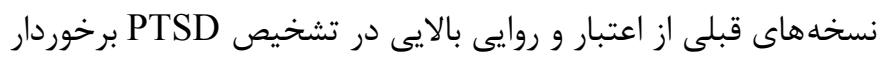

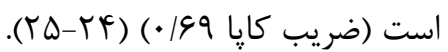

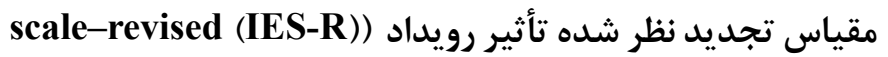

(The impact of event

اين مقياس به وسيله Meiess و Marmer (1997) هماهنخ با ملاكهاى IES-R براى تشخيص PTSD براحى و تدوين شده است DSM-IV

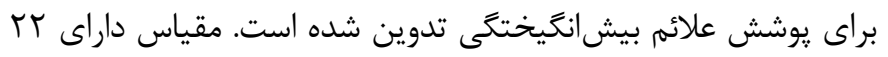

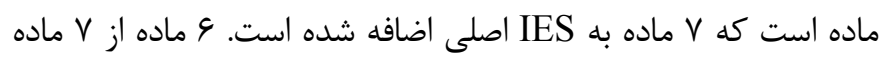

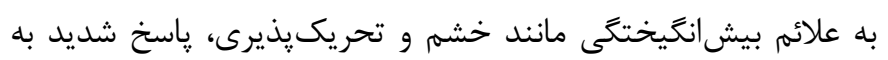

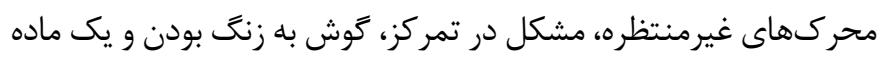

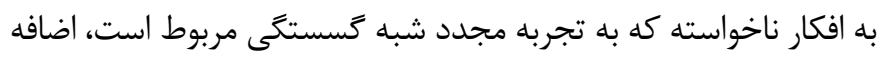

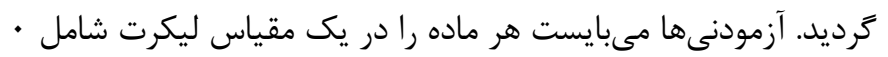

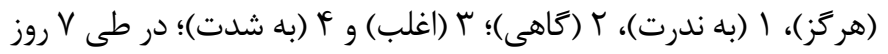

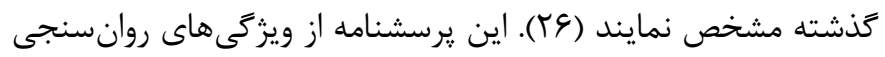

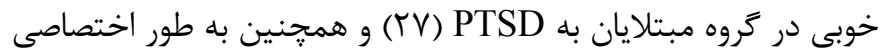

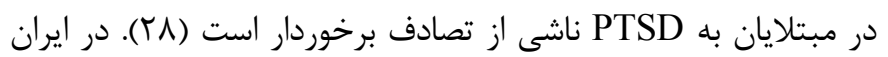

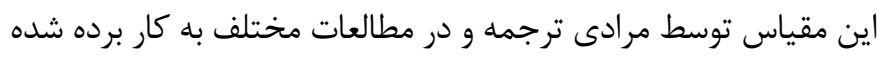

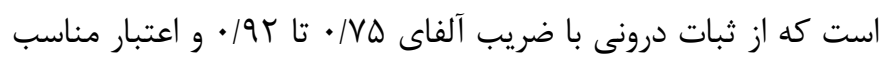

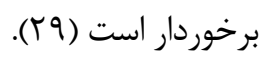

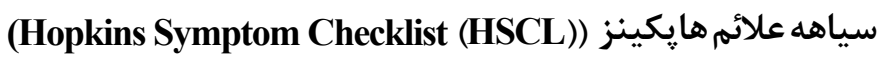
همبستخى بالاى افسردگى و اختلال PTSD لزوم كنترل علائم افسردىى

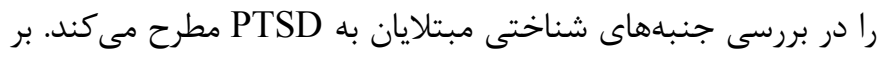
اين اساس در يزوهش حاضر براى كنترل علائم اختلال افسردىى از بخش دوم سياهه علائم Hopkins كه شامل ها ماده براى بررسى علائم

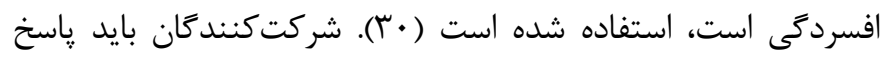

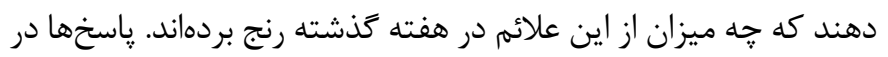

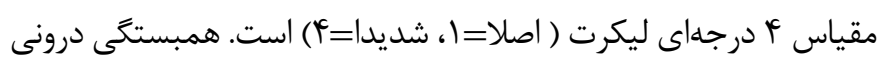

توجه مورد بررسى قرار گرفته و كمتر در ساختارهاى ديگر و يا به صورت مستقل مورد توجه واقع شده است. اين در حالى است كه مطالعات

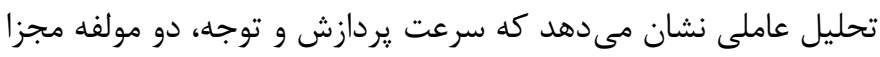

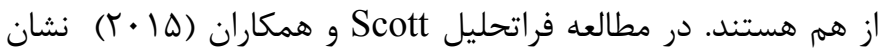
داده شد كه پِ از حافظه كارى، سرعت يردازش دومين اندازه اثر رادر

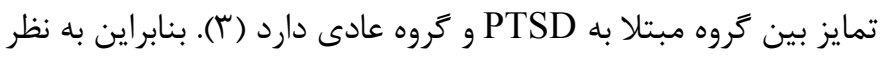

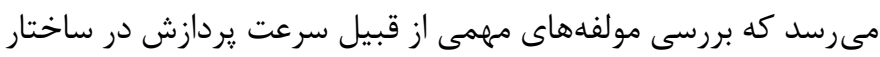

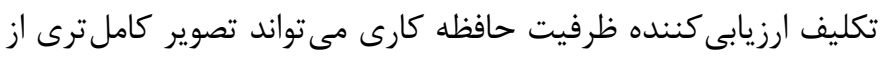

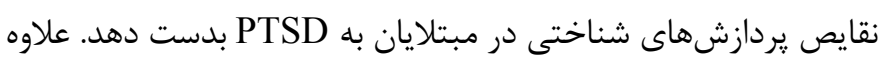

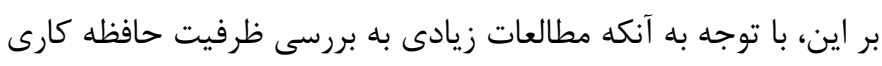

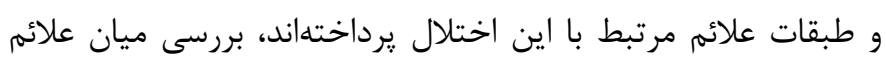

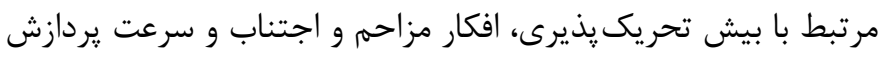

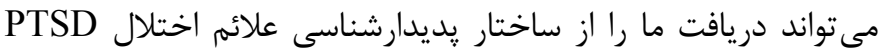

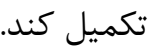
بر اين اساس مطالعه حاضر با هدف بررسى عملكرد ظرفيت حافظه كارى

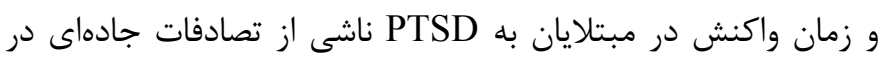

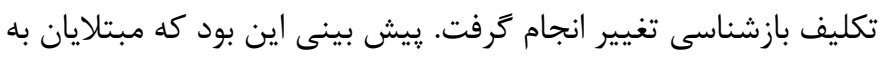

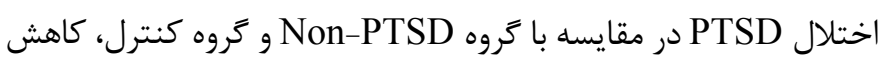
ظرفيت حافظه كارى را به صورت كلى در كل تكليف ظرفيت حافظه كارى نشان دهند. همجنين يِيشبينى ديكر اين بود كه زمان ران واكنش

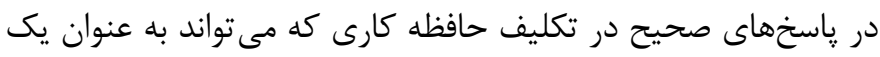

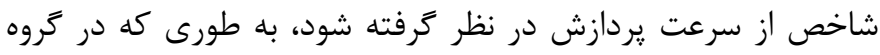
مبتلا به PTSD بيش از گروه Non-PTSD و گروه كنترل باشد.

\section{روش كار}

از •له نفر شركت كننده در مطالعه، • ب فرد مبتلا به اختلال استرس

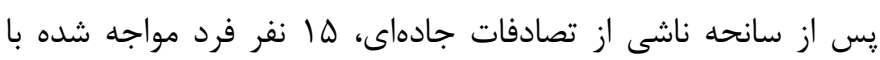

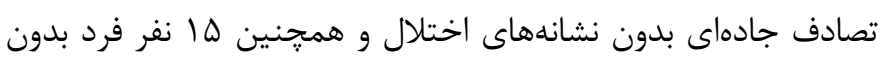

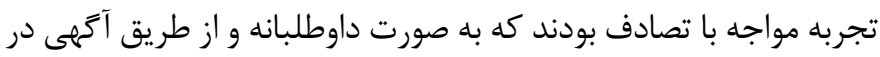
شبكههاى اجتماعى و مراجعه به بيمارستان شفا يحيائيان وارد مطالعه شدند. ابتدا مصاحبه اوليه براى بررسى ملاكهاى ورود و همجنين معرفى يزوهش و دعوت به همكارى صورت گرفت، سيس جلسه ارزيابى

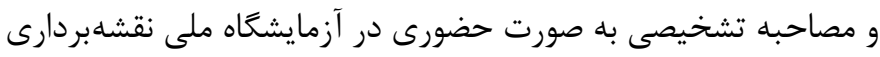

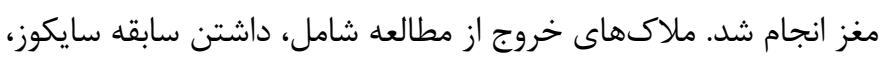

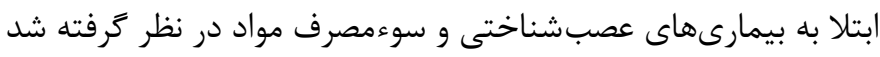

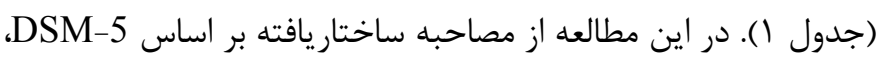

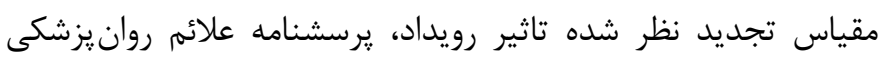


المللى (International affective picture system) استخراج شده بود (سץ). در مرحله بازيابى، مجددا دو و يا سه تصوير جهره نشان داده

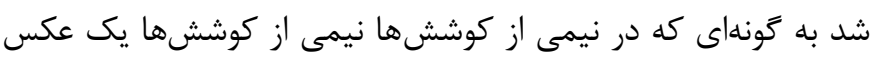

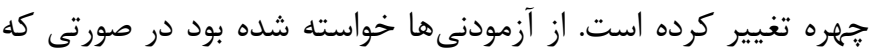
تشخيص دادند تصاوير جهره تغيير كرده است بر روى تصوير تغيير كرده كليك كنند و در صورتى كه از نظر آنها تغييرى اتفاق نيفتاده است، كليد فاصله را فشار دهند. دستورالعمل انجام تكليف بر دقت در تشخيص تغيير جهرهها در سريعترين زمان ممكن تاكيد دارد. روش اجرا: پِ انجام مصاحبه اوليه تلفنى، از واجدين شرايط

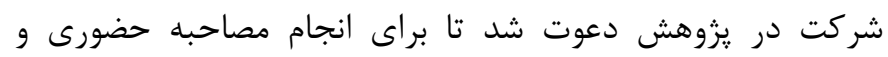
ارزيابى حافظه به آزمايشخاه ملى نقشهبردارى مغز مراجعه نمايند. ״ِ إنجام مصاحبه تشخيصى ساختاريافته در آزمايشكاه، ابتدا توضيحاتى در مورد هدف يزوهش و مطلع كردن داوطلبان از شرايط و حقوقشان در حين شركت در مطالعه به آنان داده شده و در نهايت از تمام شركتكنندكان رضايتنامه كتبى جهت شركت در مطالعه اخذ گرديد. ڤي از اين مرحله ابتدا بسته يرسشنامها و سيس ارزيابى حافظه در يك اتاق ساكت و با نور مناسب صورت كرفت. فاصله شركت كنند

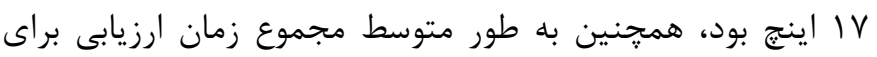
هر شركت كننده يك ساعت و نيم به طول مى انجاميد.
اين سياهه در جمعيت ايرانى 9F/ • بدست آمده كه يك اندازه عالى به شمار مى آيد (آس). تكليف ظرفيت حافظه كارى ديدارى هيجانى (Fopacity task) (Emotional working memory ميرابوالفتحى و همكاران (9 (1) با تلفيق تكليف بازشناسى استفاده شده

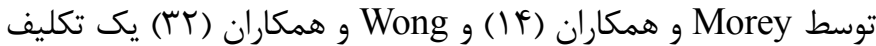
بازشناسى تغيير جهره را كه شامل تصاوير واسط مرتبط با حادثه آسيبزا (تصادف)، خنثى و مبهم (مغشوش) شده بود طراحى كردند. اين تكليف از سه مرحله، كدكذارى، نكهدارى و بازيابى تشكيل شده است. نسخه اوليه طراحى شده اين تكليف شامل •9 كوشش بود كه در اين مطالعه از نسخه بلندتر شامل •YN كوشش استفاده شده است. در نسخه اوليه اين تكليف ץ اندازه كوشش در مرحله كدكذارى در نظر كرفته شده بود (دو، سه و يا جهار عكس جهره) كه به دليل دشوارى زياد، اندازه كوشش F تصوير (19) حذف كرديده و در اين مطالعه تنها از اندازه كوشش و ץ استفاده شده است. زمان ارائه تصاوير جهره در مرحله رمز كذارى از دو و يا سه عكس جهره به صورت مساوى ץ ثانيه در نظر خرفته شد. يس از حذف تصاوير در مرحله كدگذارى، يك تصوير به مدت يك ثانيه به نمايش كذاشته مىشد. اين تصاوير كه به عنوان عوامل يرت كننده

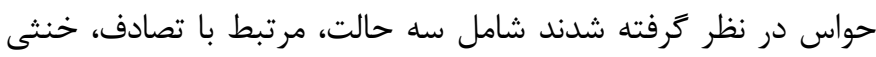

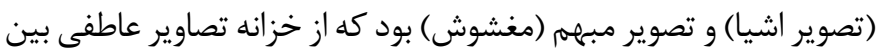

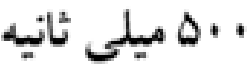
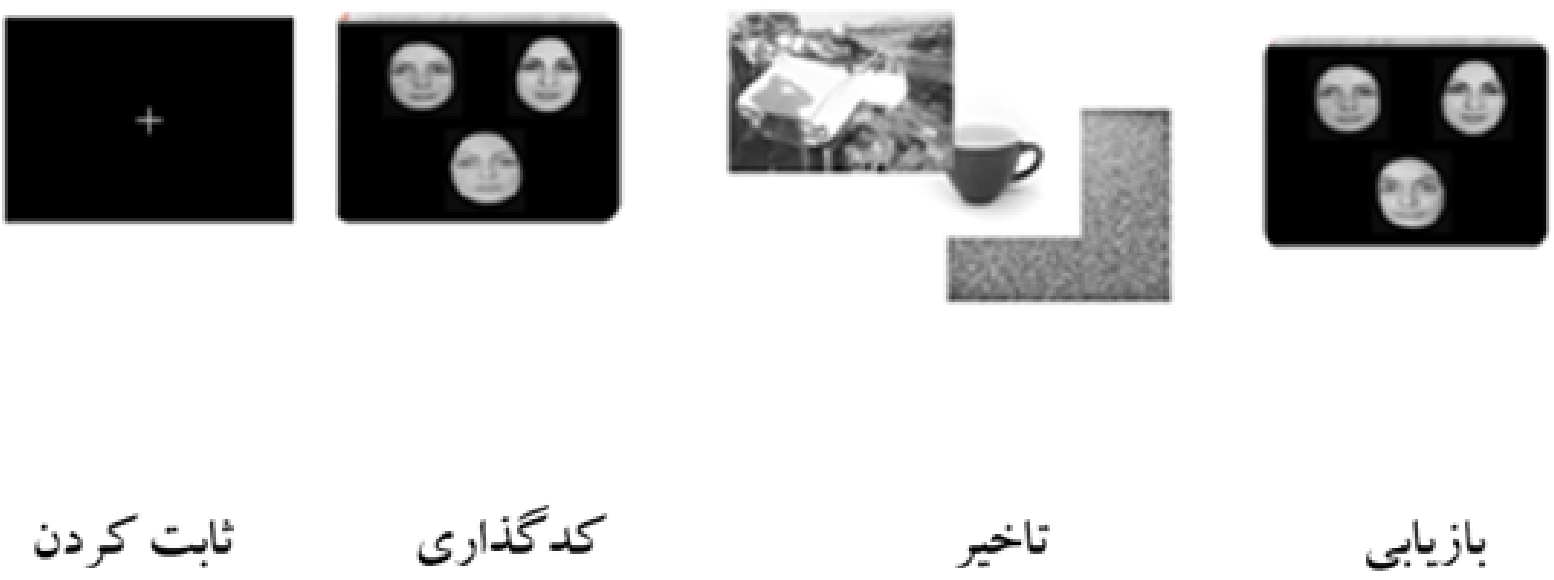

بازيابى

شكل ا.ـمراحل تكليف ظرفيت حافظه كارى هيجانى: همانطور كه در تكليف نشان داده شده است اين تكليف از سه مرحله، كدَذارى، عامل يرت كننده حواس و بازيابى تشكيل شده است. 
بافتهها

زروه Non-PTSD نمرات بالاترى را كسب كردهاند و در يرسشنامه HSCL نيز كه علائم افسردگى را مىسنجد زروه مبتلا به PTSD در مقايسه با گرووه Non-PTSD و گروه كنترل، به طور معنادارى علائم افسردگى بيشترى را ززارش كردهاند.
همانطور كه در جدول شماره 1 مشاهده مىشود، سه زروه

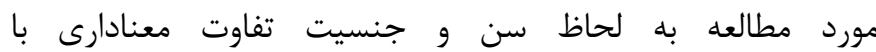
يكديگر نداشتند. همجنين گروه مبتلا به PTSD در تمام خرده مقياسهاى يرسشنامه پاسخ به رويداد به طور معنادارى از

جدول ا. اطلاعات جمعيت شناختى و نمرات برسشنامهاى مطالعه در گروه هاى يروهش

\begin{tabular}{|c|c|c|c|c|}
\hline آماره و P & كنترل & Non-PTSD & PTSD & \\
\hline$F(r, F V)=\cdot / r$ & $(\mathcal{F} / \Psi) \Gamma / \mathcal{F}$ & 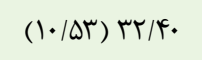 & $(1 \cdot / \Lambda T) \mu I / K$. & سن \\
\hline$\chi^{2}=\cdot / v 9$ & ها (11 & ها (rا زن) & (j) & جنسيت \\
\hline$F(Y, F V)=\mid r / r V^{* * * * *}$ & $(Y / 91) \Gamma \varepsilon / 9 q$ & س//T T (II/ & $\left(N / r_{*}\right) r_{*} / 1 \varepsilon$ & HSCL \\
\hline 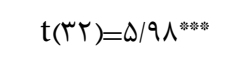 & - & $(\mid r / g F) \|$ & (IT/KG) rV/AF & IES-R \\
\hline$t(r r)=F / \varphi V^{* * * *}$ & - & $(\mathcal{F} / A V) \mathcal{F}$ & r & اجتناب \\
\hline$t(r r)=r / 9 q^{*: *}$ & - & س & $(\Delta / 9 q) \mid r / \Delta r$ & افكار مزاحم \\
\hline 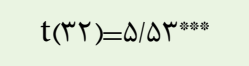 & - & $(F / \Gamma) r / F V$ & $(F / \Delta \Lambda) \mid r$ & بيش تحريك يذيرى \\
\hline
\end{tabular}

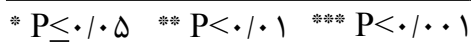

(F(l/FV)=Frq/•.9، يرت كننده حواس مختلف (مرتبط با تصادف، تصوير شى و يا مبهم)

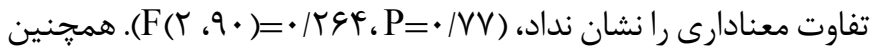
تعامل بين سه مولفه اندازه كوشش، عامل يرت كننده حواس و كروههاى

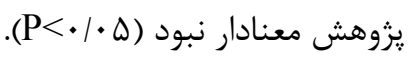
همانطور كه در نمودار 1 مشاهده مىشود، به نظر مىرسد در عامل يرت كننده حواس با محتواى مبههم (مغشوش) تمايز بيشترى بين گروهها

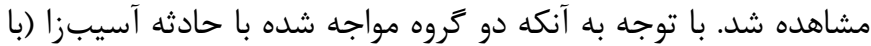
اختلال PTSD و بدون علائم اختلال PTSD) هر دو نمرات نزديك به هم را نشان مى دهند، براى بررسى تفاوت مشاهده شده، با استفاده از تحليل واريانس يك راهه نمرات حافظه كارى در دو حالت اندازه كوشش كوجى (دو تصوير) و اندازه كوشش بزرگ (سه تصوير) به صورت مجزا در دو گروه مواجه شده با حادثه آسيبزا (PTSD و Non-PTSD) در مقايسه با گروه كنترل بدون سابقه مواجه با تصادف، مورد بررسى قرار گرفت. بر اساس نتايج بدست آمده در نمره حافظه كارى در حالت اندازه كوشش بزرگ (س تصوير קهره) و تصوير واسط مبههم، بين گروه مواجه شده با حادثه آسيبزاو گرووه مواجه نشده با حادثه آسيبزا تفاوت

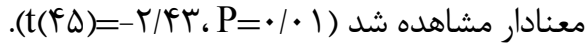

حافظه كارى ديدارى

براى محاسبه ظرفيت حافظه كارى ديدارى از شاخص صحت ياسخها استفاده شد. شاخص صحت يُاسخ از مجموع تعداد تمام ياسخهاى صحيح در تكليف محاسبه مىشود. سيس از آزمون تحليل واريانس مختلط با اندازه گيرىهاى مكرر براى محاسبه تفاوت نمره حافظه كارى در بين گروهها استفاده شد. لازم به ذكر است پيش فرضهاى انجام آزمون تحليل واريانس مختلط با

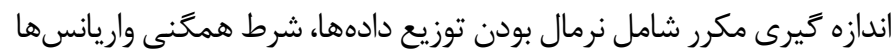
و شرط كرويت در ماتريس كوواريانس بررسى شد. براى بررسى نرمال بودن دادهها از آزمون شاييروـويك، براى بررسى شرط همخنى واريانسها از آزمون لوى و براى بررسى شرط كرويت از آزمون موخلى استفاده شد. با توجه به برآورده شدن ييش فرض هاى لازم براى انجام آزمون تحليل واريانس مختلط با اندازهخيرى مكرر مى توان از اين آزمون براى مقايسه اثرات اصلى و تعاملى مولفههاى اندازه كوششها و نوع عامل يرت كننده حواس به عنوان عامل درون گروهى و نوع گروههاى يثوهش (PTSD Non-PTSD، و كنترل) استفاده كرد.

همانطور كه يِشبينى شده بود تمام گروهها در حالت اندازه كوشش كو ¥كىتر (شامل دو تصوير جهره) نسبت به اندازه كوشش بزرگتر

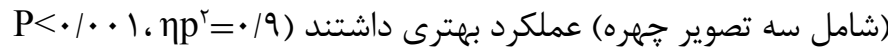



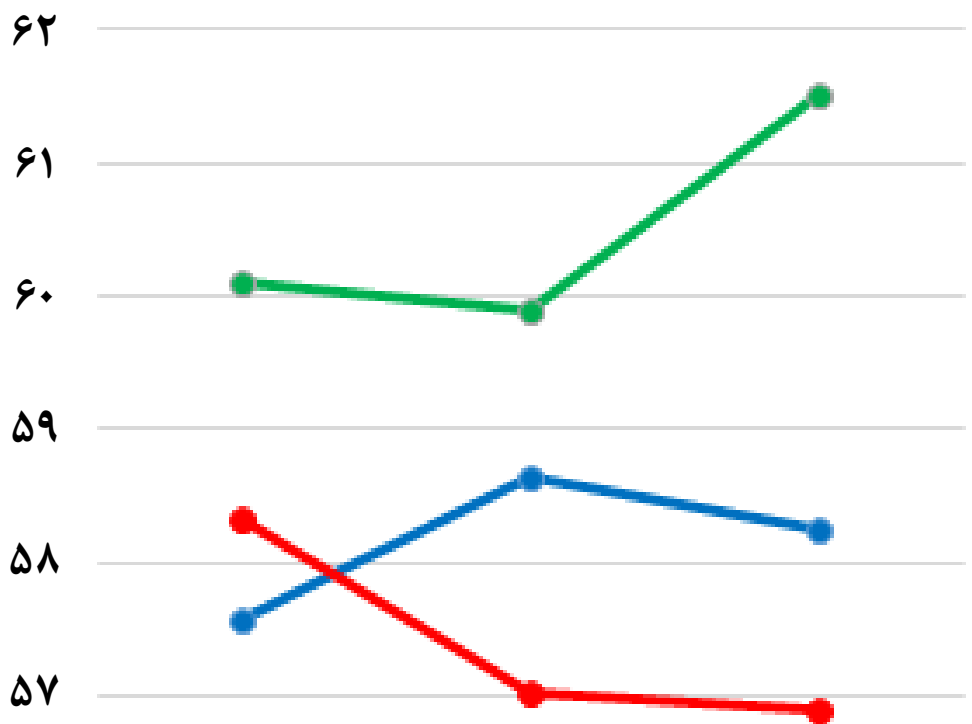

$\Delta 9$

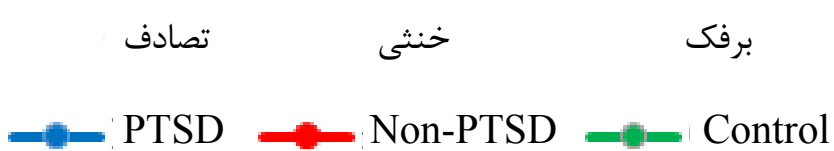

نمودار 1. نمودار تعاملى ميانگين اصلاح شده ظرفيت حافظه كارى در حالات مختلف تكليف ظرفيت حافظه كارى هيجانى

مورد مطالعه كوششهاى داراى دو تصوير و سه تصوير را در حالات

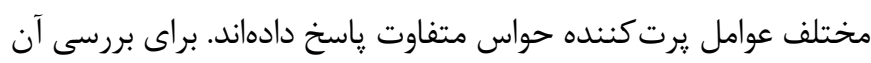

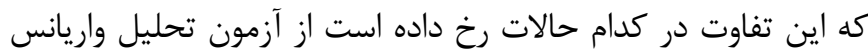
يك طرفه استفاده شد (جدول r). همانطور كه مشاهده مى شعود تفاوت بين گروهها در هر 9 حالت تكليف معنادار است.

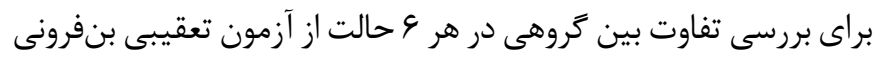

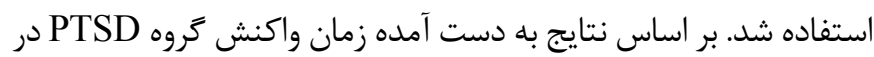

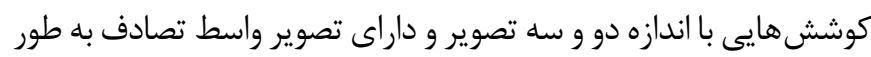

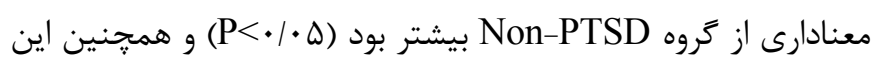
كروه در كوششهاى داراى سه تصوير همراه با تصوير واسط مبرهم نسبت

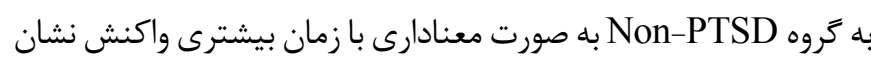

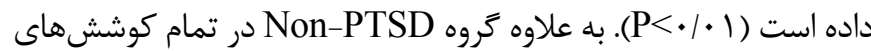

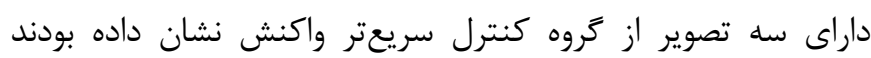

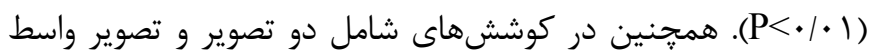
مبهم و خنثى نيز سريعتر از كروه كنترل ياسخ داده بودند (1 (P< (P<).

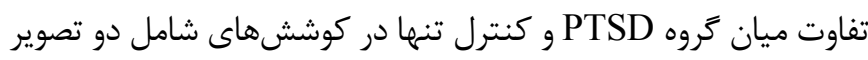
و داراى تصوير خنىى معنادار بوده (1 (P<•) و در ساير حالات تفاوت معنادارى بين اين دو گروه به دست نيامد (ه •/P> (P).
زمان واكنش در تكليف حافظه كارى ديدارى

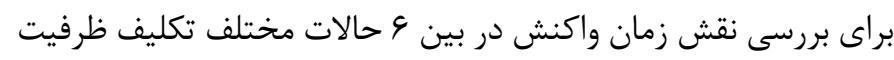
حافظه كارى از آزمون تحليل واريانس مختلط با اندازهيرىهاى

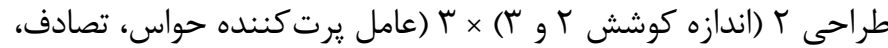
شى و مبهمم) × ץ (كروه PTSD، Non-PTSD و كنترل) استفاده شد. ابتدا بيش فرض هاى انجام آزمون تحليل واريانس مختلط با اندازهيرى مكرر شامل نرمال بودن توزيع دادهها، شرط همخنى واريانسها و شرط

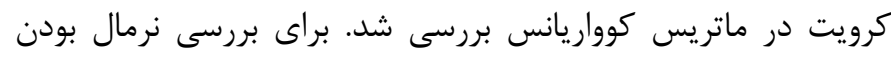

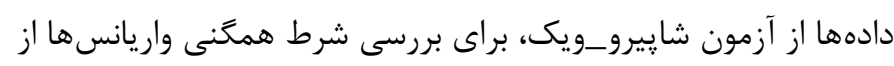

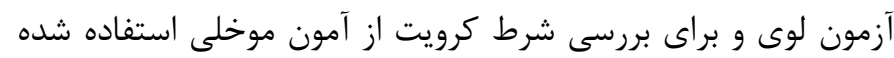

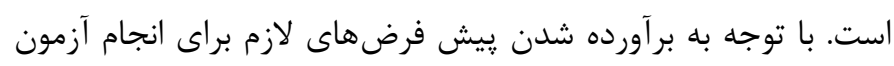

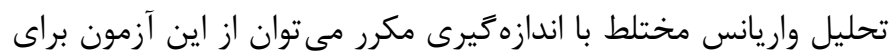
مقايسه اثرات منفرد و تعاملى مولفههاى اندازه كوششها و نوع عامل يرت كننده حواس به عنوان عامل درون گروهى و نوع گروههاى يزوهش

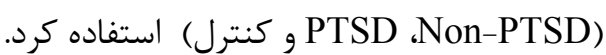
بر اساس نتايج بدست آمده، تعامل بين هر سه عوامل (اندازه كوشش،

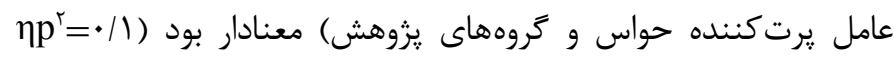

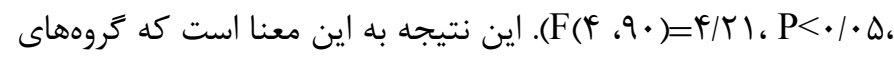


جدول r. زمان واكنش به كوششهاى دو و سه تصوير با تصاوير واسط تصادف، خنثى و برفى

\begin{tabular}{|c|c|c|c|c|c|}
\hline آماره و P & كنترل & Non- PTSD & PTSD & تصوير واسط & اندازه كوشش \\
\hline$F(r, r \Delta)=r / \varphi q \Delta^{* *}$ & $(Y \cdot N / F F) q G F / G$. & $(I I V / V T) \Lambda \cdot V / 9)$ & $(Y \& E / Y) Q N \mathrm{~N} / \mathrm{r}$ & تصادف & \multirow{3}{*}{ دو تصوير } \\
\hline$F(\tau, Y \Delta)=\varphi|\Lambda| \Lambda^{* * * a}$ & $(r \cdot \Lambda / 9) 11 K r / 1 r$ & $(1 \Delta 9 / \wedge) \wedge \cdot \cdot / 9 \Delta$ & $(T \cdot T / T) q T Y / \Lambda \Delta$ & خنثى & \\
\hline$F(T, F \Delta)=1 \cdot / T^{w}$ & (TDI/T) $1 . q K / \cdot 1$ & (QN/D) AKr/rV & $(191) 91 V / \cdot 4$ & برفك & \\
\hline$F(r, r \Delta)=r / V \uparrow \varphi^{*}$ & $(\mid Q I / V)) \cdot V V / q F$ & $(T r \cdot / r) V V V / T r$ & $(T V V / 1) 99 \Delta / 4 \&$ & تصادف & \multirow{3}{*}{ سه تصوير } \\
\hline 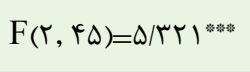 & $(\mid \Lambda Y / \cdot F) \mid \cdot r F / I I$ & (TG./T) VAF/rqq & $(T \Lambda T / 9)$ qRF/G & خنثى & \\
\hline$F(r, r \Delta)=V / \cdot r V^{* \text { *as }}$ & $(194 / V) 1 \cdot r / / V \Delta$ & $(19 \% / r) V V r / 9 \Lambda$ & $(T H / \Lambda) 1 . \mid F / A F$ & برفك & \\
\hline
\end{tabular}

${ }^{*} \mathrm{P} \leq \cdot / \cdot \Delta \quad{ }^{* * *} \mathrm{P}<\cdot / \cdot 1 \quad{ }^{* * * * *} \mathrm{P}<\cdot / \cdot \cdot 1$

شامل دو تصوير و داراى تصوير خنثى معنادار بوده ( (P< (P) و در ساير

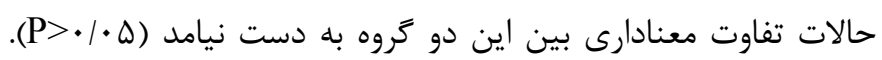

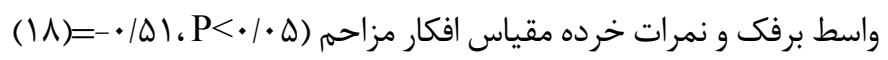

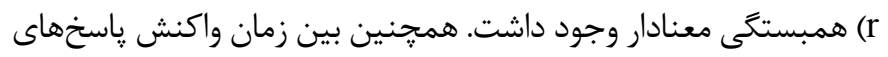

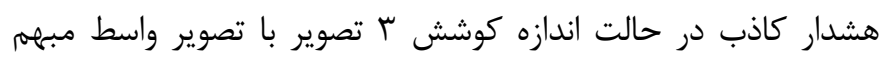

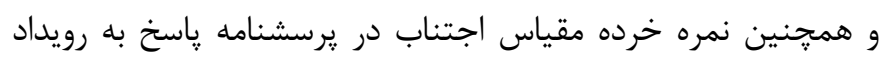

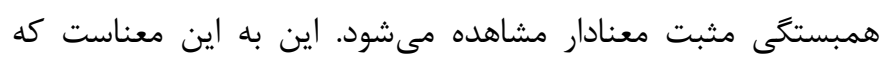

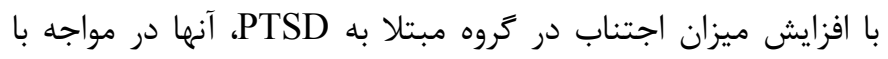

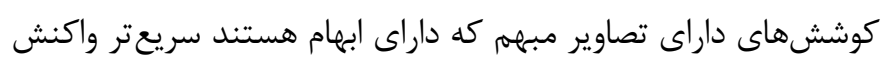
نشان مى دهند (r)
همبستكى بين زمان واكنش در تكليف حافظه كارى و علائم

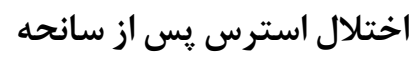

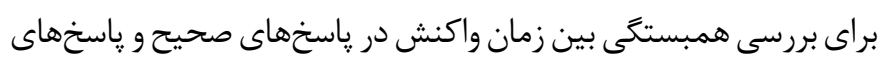
هشدار كاذب در بين حالتهاى مختلف تكليف حافظه كارى ديدارى و ودئي نمرات به دست آمده در خرده مقياسهاى يرسشنامه پِاسخ به رويداد از هاز

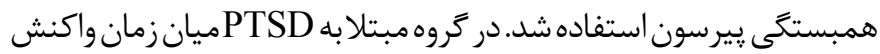
خاسخهاى صحيح به كوششهاى داراى تصوير واسط تصادف و نمرات

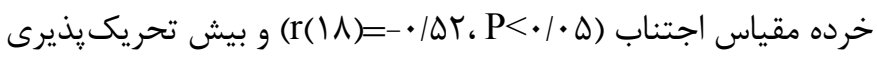

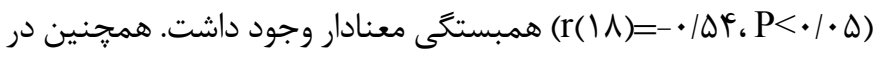

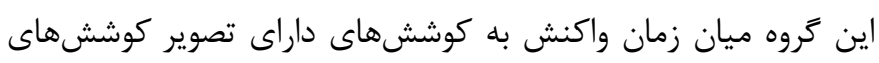
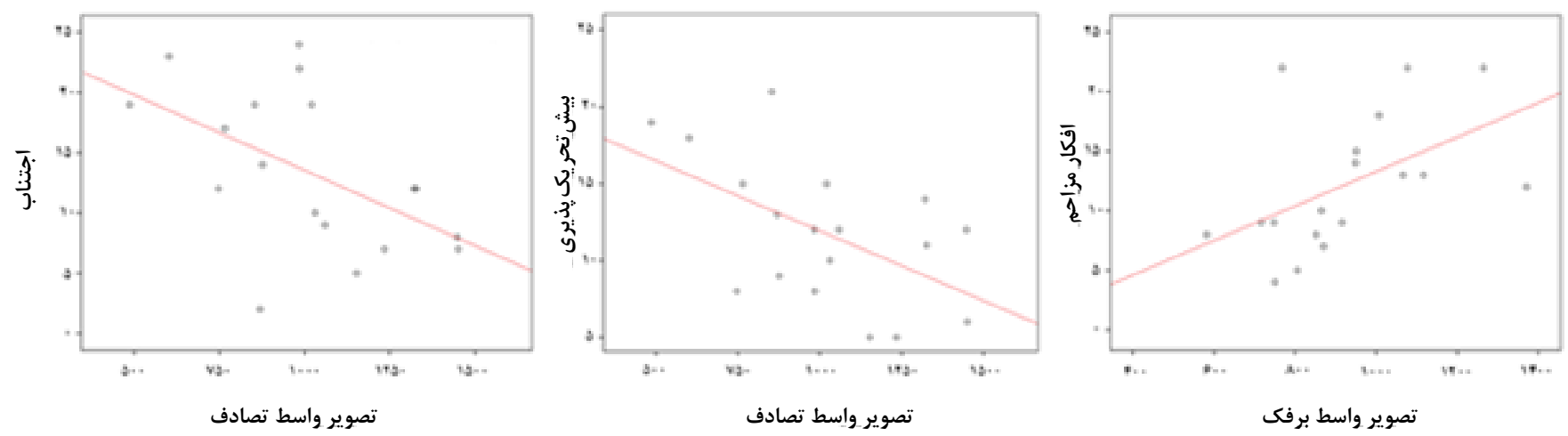

نمودار r. همبستخى ميان خرده مقياس هاى يرسشنامه تاثير رويداد و زمان واكنش ياسخهاى صحيح در كوششهاى داراى ب تصوير 


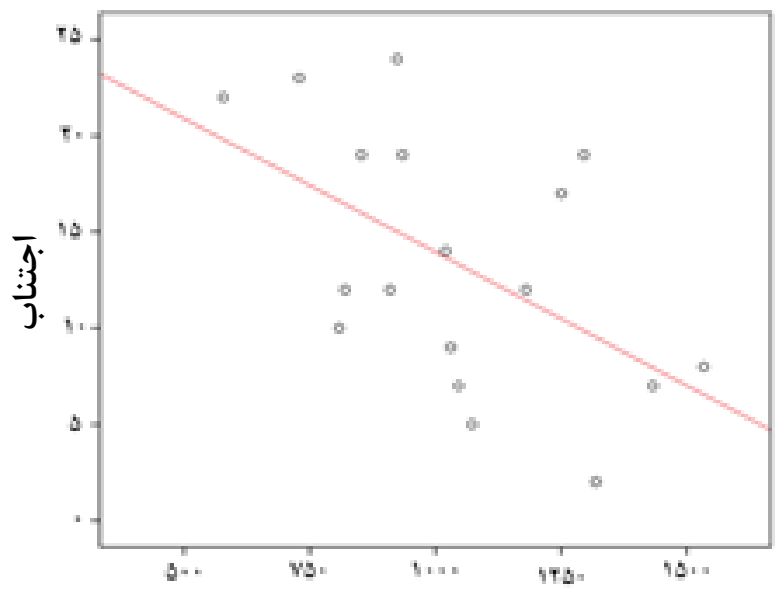

تصوير واسط برفك

نمودار r. همبستكى ميان خرده مقياس اجتناب از برسشنامه تاثير رويداد و زمان واكنش ياسخهاى هشدار كاذب در كوششهاى داراى ؟ تصوير با تصوير واسط برفك

PTSD در موقعيت كوششهايى با بار شناختى زياد (سه تصوير در مرحله كد كذارى) و همراه با محرك مبهم قرار گرفته بودند. اين گونه كه به نظر مىرسد در كوششهاى دشوارتر، مواجه با ابهام با افزايش

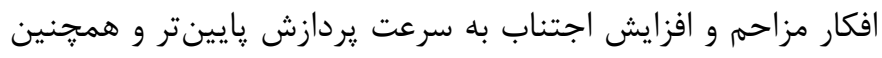

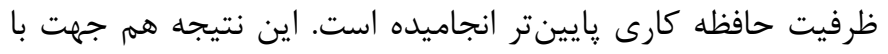

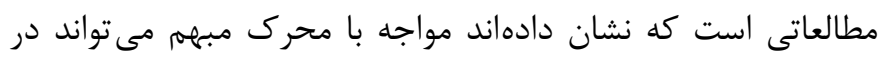

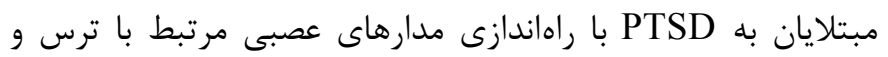

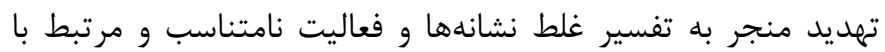
ترس سيستم عصبى و شناختى گردد (IV). بر اساس نظريه سو توجه افراد مبتلا به PTSD گرايش به تفسير منفى از نشانههاى مبههم و خنثى دارند كه همين مساله مى تواند تبيين كننده نقش منفى مواجه

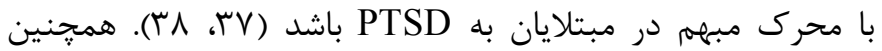
مدل كنترل شناختى بيان مى كند كه نقص در تنظيم عصبى بالا

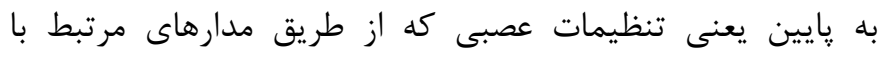

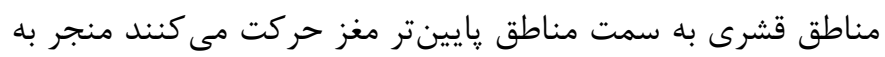

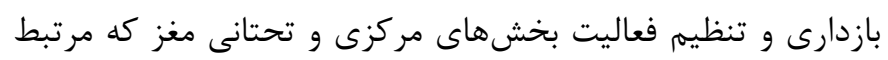
با يردازش هيجانات هستند مى كردند و اين كونه مى تواند منجر واكنش شديد هيجانى در مواجه با محرك مبهم كردد و علائمى همجون بيش گوش به زنكى را در مبتلايان به اين اختلال ايجاد كنند (1)(1). علاوه بر اين از منظر نشانهشناسى مى توان كَفت كه مواجه با محرك مبهرم با راهاندازى اشتغال به افكار مزاحم منجر به تشديد

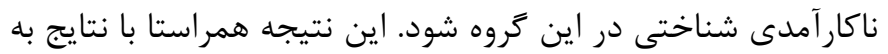

در اين مطالعه به بررسى ناكارآمدى شناختى از منظر ظرفيت حافظه كارى هيجانى و سرعت يردازش در مبتلايان به PTSD يرداخته شده بود. هم جهت با پِيشبينى صورت گرفته، ظرفيت حافظه كارى در كوششهاى شامل دو تصوير (بار شناختى كم)

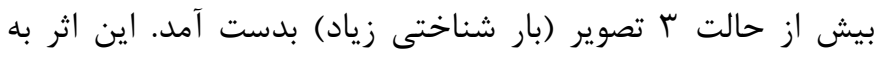

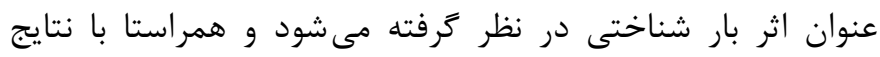

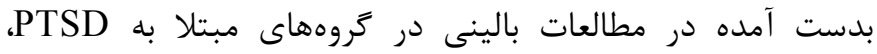
اضطراب و يا افسردگى و بررسىهاى انجام شده در افراد عادى است

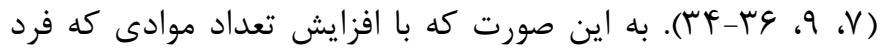
در هنكام انجام تكليف ارزيابى كننده ظرفيت حافظه كارى ملزم به نكَهدارى و انجام محاسبه روى آنها است، ميزان باسخهاى صحيح به طور معنادار كاهش پِيدا مى كند. در بررسى اثر مواجه با عوامل يرت كننده حواس هيجانى و خنىى بر ظرفيت حافظه كارى، بر خلاف نتايج بدست آمده از مطالعات

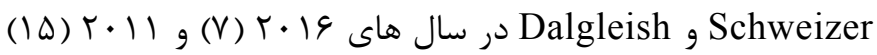
است كه حاكى از كاهش ظرفيت حافظه كارى در مبتلايان به PTSD در مواجه با عوامل يرت كننده حواس مرتبط با حادثه آسيبزا بود. بر إنان اساس نتايج بدست آمده در اين مطالعه، تصاوير مبهمم در گروه مبتلا به PTSD اثر حه از منظر ظرفيت حافظه كارى و جه از منظر سرعت يردازش و جهـ همبستكى ميان علائم اختلال و سرعت يردازش، به صورت يكيارجه

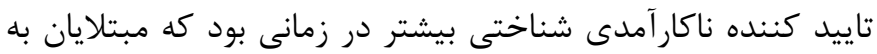




\section{نتيجه كَيرى}

در اين مطالعه زمان واكنش در ياسخهاى صحيح و ياسخهاى شامل هشدار كاذب مورد بررسى قرار گرفت، همانطور كه ييشبينى شده بود به طور كلى زمان واكنش در ياسخهاى صحيح در گروه مبتلا به PTSD بيش از زروه Non-PTSD بوده و نكته بسيار مهلم آن است كه اين شاخص نسبت به ظرفيت حافظه كارى توانسته تمايز بيشترى را در بين گروههاى يروهش ايجاد كند كه نياز به بررسى بيشتر در مطالعات

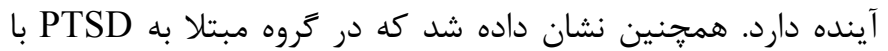
افزايش ميزان اجتناب و بيش تحريكيذيرى سرعت پاسخ در مواجه با محركهاى مرتبط با تصادف افزايش مى يابد. به عبارت ديگر به نظر مى رسد كه ماهيت علائم مرتبط با بيش تحريك يذيرى كه به بالا رفتن سطح گوش به زنگى و هشدار نسبت به محركهاى مرتبط با حادثه آسيبزا منجر مىشود از يك سو و همجنين ترس از مواجه شدن با سرنخهاى مرتبط با حادثه آسيبزا از سوى ديخر، به واكنش سريعتر و فعاليت بيشتر سيستم حافظه كارى منجر شده است.

\section{تشكر و قدرواذى}

اين مطالعه با حمايت مالى ستاد توسعه علوم شناختى و آزمايشگاه ملى نقشهبردارى مغز صورت گرفته است.

\section{References}

1. American Psychiatric Association. Diagnostic and statistical manual of mental disorders (DSM-5®). Arlington VA:American Psychiatric Association;2013.

2. Morey R, Brown VM. Neural systems for cognitive and emotional processing in posttraumatic stress disorder. Frontiers in Psychology. 2012;3:00449.

3. Scott JC, Matt GE, Wrocklage KM, Crnich C, Jordan J, Southwick SM, et al. A quantitative meta-analysis of neurocognitive functioning in posttraumatic stress disorder. Psychology Bulletin. 2015;141(1):105-140.

4. Baddeley A. The episodic buffer: A new component of working memory?. Trends in Cognitive Sciences. 2000;4(11):417-423. 5. Redick TS, Wiemers EA, Engle RW. The role of proactive interference in working memory training and transfer. Psychol-
دست آمده در مطالعاتى است كه بيان مى كنند ابهام باعث افزايش نشخوار فكرى و كاهش ظرفيت حافظه كارى مىشود (·ץ-ץ). در مطالعه حاضر تنها از تصاوير جهره بانوان براى طراحى تكليف استفاده شد، ييشنهاد مى شود كه در مطالعات آينده از تصاوير هر بر بران دو جنسيت و يا ساير تصاوير مانند اشكال هندسى جهت استفاده در مرحله رمزگذارى استفاده شود. همجنين با توجه به آن كه بررسى بـ ظرفيت حافظه كارى ديدارى در مبتلايان به PTSD داراى نتايج يكيارجه نبوده به نظر مىرسد كه يك مطالعه مقايسه كه ظرفيت حافظه كارى ديدارى و همجنين كلامى را به صورت مجزا در اين دو گروه مورد ارزيابى قرار دهد بتواند تصوير روشنترى از نقايص شناختى در دو حوزه متفاوت در اين گروه بدست دهد. در نهايت با توجه به نتايج حاصل از اين مطالعه كه بيان كننده حساسيت شديد مبتلايان به PTSD در مواجه با محركهاى مبرهم است، طراحى و

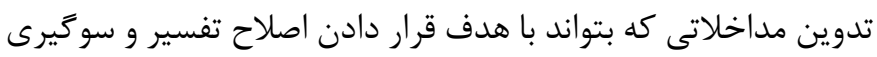

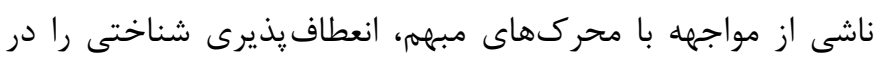

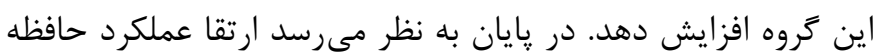
كارى در بافتى از عوامل يرت كننده حواس مبهـم، مىتواند كاهش سطح تحريك يذيرى در مبتلايان به اين اختلال را موجب شده و در افزايش عملكرد شناختى اين گروه موثر واقع گردد.

ogy Research. 2019:1-20.

6. Ehring T, Frank S, Ehlers A. The role of rumination and reduced concreteness in the maintenance of posttraumatic stress disorder and depression following trauma. Cognitive Therapy and Research. 2008;32(4):488-506.

7. Schweizer S, Dalgleish T. The impact of affective contexts on working memory capacity in healthy populations and in individuals with PTSD. Emotion. 2016;16(1):16-23.

8. Frischkorn GT, Schubert AL, Hagemann D. Processing speed, working memory, and executive functions: Independent or inter-related predictors of general intelligence. Intelligence. 2019;75:95-110.

9. Schubert AL, Hagemann D, Voss A, Bergmann K. Evaluating the model fit of diffusion models with the root mean square 
error of approximation. Journal of Mathematical Psychology. 2017;77:29-45.

\section{Aupperle RL, Allard CB, Grimes EM, Simmons AN, Flag-} an T, Behrooznia M, et al. Dorsolateral prefrontal cortex activation during emotional anticipation and neuropsychological performance in posttraumatic stress disorder. Archives of General Psychiatry. 2012;69(4):360-371.

11. Kieseppä T, Tuulio-Henriksson A, Haukka J, Van Erp T, Glahn D, Cannon TD, et al. Memory and verbal learning functions in twins with bipolar-I disorder, and the role of information-processing speed. Psychological Medicine. 2005;35(2):205-215.

12. Zaremba D, Kalthoff IS, Förster K, Redlich R, Grotegerd D, Leehr EJ, et al. The effects of processing speed on memory impairment in patients with major depressive disorder. Progress in Neuro-Psychopharmacology and Biological Psychiatry. 2019;92:494-500.

13. Ojeda N, Peña J, Sánchez P, Elizagárate E, Ezcurra J. Processing speed mediates the relationship between verbal memory, verbal fluency, and functional outcome in chronic schizophrenia. Schizophrenia Research. 2008;101(1-3):225-233.

14. Morey RA, Dolcos F, Petty CM, Cooper DA, Hayes JP, LaBar KS, et al. The role of trauma-related distractors on neural systems for working memory and emotion processing in posttraumatic stress disorder. Journal of Psychiatric Research. 2009;43(8):809-817.

15. Schweizer S, Dalgleish T. Emotional working memory capacity in posttraumatic stress disorder (PTSD). Behavior Research and Therapy. 2011;49(8):498-504.

16. Mazza M, Tempesta D, Pino MC, Catalucci A, Gallucci M, Ferrara M. Regional cerebral changes and functional connectivity during the observation of negative emotional stimuli in subjects with post-traumatic stress disorder. European Archives of Psychiatry and Clinical Neuroscience. 2013;263(7):575-583.

17. Weber DL. Information processing bias in post-traumatic stress disorder. The Open Neuroimaging Journal. 2008;2:29-51. 18. White SF, Costanzo ME, Blair JR, Roy MJ. PTSD symptom severity is associated with increased recruitment of top-down attentional control in a trauma-exposed sample. NeuroImage: Clinical. 2015;7:19-27.

19. Mirabolfathi V, Moradi A, Bakhtiari M. Emotional working memory in post traumatic stress disorder and depression. Advances in cognitive sciences. 2016;17(4):23-44. (Persian)

20. Mirabolfathi V, Moradi A, Jobson L. Influence of affective distractors on working memory capacity in relation to symptoms of posttraumatic stress disorder. Applied Cognitive Psychology. 2019;33(5):904-910.

21. Eysenck MW, Derakshan N. New perspectives in attentional control theory. Personal Individual Difference. 2011;50(7):955-960.

22. Aupperle RL, Melrose AJ, Stein MB, Paulus MP. Executive function and PTSD: Disengaging from trauma. Neuropharmacology. 2012;62(2):686-694.

23. First MB, Williams JBW, Karg RS, Spitzer RL. Structured clinical interview for DSM-5 disorders: SCID-5-CV clinician version. Washington, DC:American Psychiatric Association Publishing;2016.

24. Regier DA, Narrow WE, Clarke DE, Kraemer HC, Kuramoto SJ, Kuhl EA, et al. DSM-5 field trials in the United States and Canada, Part II: Test-retest reliability of selected categorical diagnoses. American Journal of Psychiatry. 2013;170(1):59-70.

25. Zawadzki B, Popiel A, Cyniak-Cieciura M, Jakubowska B, Pragłowska E. Diagnosis of Posttraumatic Stress Disorder (PTSD) by the Structured Clinical Interview SCID-I. Psychiatria Polska. 2015;49(1):159-169.

26. Weiss DS, Marmar CR. The impact of event scale-revised. In: Wilson JP, Keane TM, editors. Assessing psychological trauma and PTSD. New York:Guilford Press;1997. pp. 399-411.

27. Creamer M, Bell R, Failla S. Psychometric properties of the Impact of Event Scale-Revised. Behavior Research and Therapy. 2003;41(12):1489-1496.

28. Beck JG, Grant DM, Read JP, Clapp JD, Coffey SF, Miller LM, et al. The impact of event scale-revised: Psychomet- 
ric properties in a sample of motor vehicle accident survivors. Journal of Anxiety Disorder. 2008;22(2):187-198.

29. Moradi AR, Herlihy J, Yasseri G, Shahraray M, Turner S, Dalgleish T. Specificity of episodic and semantic aspects of autobiographical memory in relation to symptoms of posttraumatic stress disorder (PTSD). Acta Psychologica. 2008;127(3):645-653.

30. Derogatis LR, Lipman RS, Rickels K, Uhlenhuth EH, Covi L. The Hopkins Symptom Checklist (HSCL): A self-report symptom inventory. Behavioral Science. 1974;19(1):1-15.

31. Jobson L, Moradi AR, Rahimi-Movaghar V, Conway MA, Dalgleish T. Culture and the remembering of trauma. Clinical Psychological Science. 2014;2(6):696-713.

32. Wong JH, Peterson MS, Thompson JC. Visual working memory capacity for objects from different categories: A face-specific maintenance effect. Cognition. 2008;108(3):719-731.

33. Lang PJ, Bradley MM, Cuthbert BN. International affective picture system (IAPS): Affective ratings of pictures and instruction manual (Report No. A-8). Gainesville, FL:University of Florida, NIMH Center for the Study of Emotion and Attention;2008.

34. Eysenck M, Payne S, Derakshan N. Trait anxiety, visuospatial processing, and working memory. Cognition \& Emotion. 2005;19(8):1214-1228.
35. Richards A, French CC, Keogh E, Carter C. Test-Anxiety, inferential reasoning and working memory load. Anxiety Stress Coping. 2000;13(1):87-109.

36. Moran TP. Anxiety and working memory capacity: A meta-analysis and narrative review. Psychology Bulletin. 2016;142(8):831-864.

37. Iacoviello BM, Wu G, Abend R, Murrough JW, Feder A, Fruchter E, et al. Attention bias variability and symptoms of posttraumatic stress disorder. Journal of Traumatic Stress. 2014;27(2):232-239.

38. Dalgleish T, Moradi AR, Taghavi MR, Neshat-Doost HT, Yule W. An experimental investigation of hypervigilance for threat in children and adolescents with post-traumatic stress disorder. Psychological Medicine. 2001;31(3):541-547.

39. Suslow T, Wildenauer K, Günther V. Ruminative response style is associated with a negative bias in the perception of emotional facial expressions in healthy women without a history of clinical depression. Journal of Behavior Therapy and Experimental Psychiatry. 2019;62:125-32.

40. Eisma MC, Rinck M, Stroebe MS, Schut HA, Boelen PA, Stroebe W, et al. Rumination and implicit avoidance following bereavement: An approach avoidance task investigation. Journal of Behavior Therapy and Experimental Psychiatry. 2015;47:84-91. 